\title{
DNA ploidy and morphology of colon tumors in the adenoma-carcinoma sequence
}

\author{
Judith Staarmann ${ }^{1}$, Waleed F.A. Kotb ${ }^{2}$, Iver Petersen ${ }^{1}$ \\ ${ }^{1}$ Institute of Pathology, Universitätsklinikum Jena, Germany \\ ${ }^{2}$ Institute of Pathology, Universitätsmedizin Berlin, Campus Charité Mitte, Berlin, Germany (present \\ address: Clinic of Urology, Evangelisches Krankenhaus Paul Gerhardt Stift, Wittenberg, Germany)
}

\begin{abstract}
Introduction. Chromosomal changes are widespread in the vast majority of colon carcinomas and aneuploidy is an established prognostic factor. However, this knowledge so far has no influence on tumor classification. We reported a morphology-based classification scheme, the core classification, that correlates with DNA ploidy. In particular, tripolar mitoses were identified as surrogate markers of a near triploid DNA content. In addition, a survey on chromosome numbers and survival rates in carcinomas suggested that triploidy as a particular state of aneuploidy may be correlated with a more aggressive tumor phenotype. We therefore aimed to analyse DNA ploidy in the colorectal adenoma-carcinoma sequence.

Material and methods. The study collection consisted of 15 adenomas and 15 adenocarcinomas of 10 patients. Some of them showed a morphological transition between benign and malignant tumor components which were selectively analysed by DNA measurements. In addition, we assessed the morphological parameters of the core classification.

Results. The main findings of the study may be summarized as follows. 1) DNA ploidy changes are already consistently detectable in colon adenomas. They are usually associated with hyperdiploidy. 2) Adenoma tissue adjacent to carcinomas, however, may carry a hypodiploid DNA content while the nearby carcinoma samples were hyperdiploid. Hypodiploidy may thus represent a transition state to near triploid carcinomas. 3) The size of tumor nuclei and mitoses usually reflects the ploidy level of colon tumors. Specifically, triploid mitoses may point to a near triploid DNA content. 4) Triploidy per se cannot be equated with tumor aggressiveness as it may already be found in adenocarcinoma in situ. 5) Tripolar and tetrapolar mitoses in invasive colon cancer, however, are potential indicators of an advanced chromosomal instability and seemed to be associated with advanced tumor stages.

Conclusions. We present data that hypodiploidy may represent a transition state from adenoma to carcinoma in a subset of colorectal tumors and that near-triploidy may be associated with a more aggressive course of the disease. However, the interpretation of tripolar mitoses and triploidy is largely dependent on the cell type (benign vs. malignant) and tissue context (invasive vs. non-invasive cancer). Furthermore, its interpretation may be distinct for different tumor stages and histotypes. Aneuploidy and multipolar mitoses are frequent findings in cancer cells. Their relevance for tumor biology deserves further studies. (Folia Histochemica et Cytobiologica 2015, Vol. 53, No. 1, 11-18)
\end{abstract}

Key words: colon carcinogenesis; ploidy; triploidy; multipolar mitosis; adenoma-carcinoma sequence

Correspondence address: I. Petersen, M.D.

Institute of Pathology, Universitätsklinikum Jena

Ziegenmühlenweg 1, D-07740 Jena

tel.: +493641933120

e-mail: iver.petersen@med.uni-jena.de

\section{Introduction}

Colorectal cancer is with one million new cases and with over 500,000 deaths per year the third most common cancer worldwide and a leading health problem [1]. In 2008, 1.2 million new cases were diagnosed 
and about 600,000 deaths were recorded [2]. In Germany, it is the second most frequent and also the second most deadly cancer type [3]. However, it can be treated to full recovery if diagnosed at an early stage [4].

Colon cancer comprises various types of tumors [5]. Approximately $70 \%$ of colon carcinomas develop from an adenoma. The adenoma-carcinoma sequence refers to the development of cancer in the context of a previous adenoma. The probability of developing cancer increases with an increased number of adenomas in the colon. Villous polyps in particular are considered high risk. The investigation in the St. Mark's Hospital (London, UK) on 2506 patients revealed that tubular adenomas $(75 \%)$ occur much more frequently than the villous adenomas (10\%). With respect to malignancy, it was found that only $4 \%$ of tubular adenomas but $40 \%$ of villous adenomas developed into carcinoma [6]. It may take about 10 years for an adenomatous polyp to transform into cancer [7].

The growth pattern of colon adenomas is also an important feature in the definition of the degree of epithelial dysplasia which is usually divided into three degrees of severity (mild, moderate and severe) or two grades, i.e. low grade and high grade adenomas $[5,8]$. The degree of epithelial dysplasia is related to the extent of aneuploidy in adenomas. In carcinomas, in contrast, there is no correlation between the degree of malignancy and aneuploidy [9].

The histological structure of a severe dysplasia is similar to a carcinoma in situ [10]. Adenomas with mild dysplasia develop only rarely into cancer and it has been reported that the size and the type of adenoma are related to the DNA aneuploidy. Adenomas with a size smaller than $1 \mathrm{~cm}$ had no signs of aneuploidy. In contrast, larger adenomas had a significant increase in DNA aneuploidy and tubulovillous adenomas had the highest frequency of DNA changes [11].

The adenoma-carcinoma sequence is the morphological correlate of the meanwhile accepted fact that colon cancer is caused by the accumulation of genetic defects $[12,13]$. Genomic instability has been considered the engine of tumorigenesis and specifically colorectal carcinoma development may be facilitated by genetic instability that can arise in the context of familial cancer syndromes [14].

It is important to note that in an early stage of cancer, there can be inactivation of the APC (adenomatous polyposis coli) gene, RAS mutation and loss of p53 [15]. Tumors are formed by a series of specific gene mutations and many more have been meanwhile reported $[16,17]$. The oncogenic process is related to multiple pathways $[16,18]$. In addition it is based on genomic instability which is generally associated with chromosomal changes [19]. The changes of the DNA content reflect the chromosomal changes which play an important role in tumorigenesis [20,21]. DNA alterations can occur in adenomas, hyperplastic polyps, normal colon mucosa and ulcerative colitis even without dysplasia [5, 22, 23]. It has been suggested that aneuploidy is an early sign of carcinogenesis [22].

The aim of this study was to investigated the DNA content of colon tumors in the adenoma-carcinoma sequence.

\section{Material and methods}

Tumor collection. Tissue samples of 10 patients were used. They were diagnosed and treated at the Berlin Charite Hospital and the Jena University Hospital between 2003 and 2008. In total, the material consists of 15 adenomas and 15 carcinomas. The study investigated at least one tumor and one adenoma from each patient. Specimens originated from 6 male and 4 female patients, several of them had multiple tumors. The patients were on average 63 years old spanning an age range of 50 to 78 years. Patient and sample characteristics are provided in Table 1.

Light microscopic examination. In total, we analysed 30 formalin-fixed and paraffin embedded tissue samples. The histopathological analysis was based on haematoxylin-eosin ( $\mathrm{H} \& \mathrm{E})$ stained $5 \mu \mathrm{m}$ thick sections. The slides were evaluated morphologically according to the core classification which is based on cytomorphological criteria, in particular the size of the tumor nuclei and mitoses [24, 25]. In each slide at least 10 random fields were examined to judge at higher magnifications $(\times 200$ and $\times 400)$ the predominant size of the tumor nuclei and their size variability. The nuclei sizes were classified on a scale ranging from small (score 1), medium (score 2), large (score 3) to giant (score 4) using non-tumor cells, in particular lymphocytes, as reference [24]. Also the mitosis size was classified in the same manner. In addition, the presence of tripolar and/or tetrapolar mitoses was recorded [24, 25]. All parameters are listed in Table 1.

Measurement of DNA content in cell nuclei stained by Feulgen method. To select for specific tumor areas, e.g. adenoma adjacent to a carcinoma, two punches of tumor tissue of the size of $1.0 \mathrm{~mm}$ each were removed from the paraffin block. These tissue samples were deparaffinised with xylene and rehydrated by passing through a graded series of alcohol concentrations. The material was then transferred to a $12 \mathrm{~mL}$ tube for the pepsin digestion $(5 \mathrm{~mL} 0.07 \mathrm{M} \mathrm{HCl}$ supplemented by $25 \mathrm{mg}$ pepsin, Serva, Germany, catalogue No. 31820) which was performed for around $90 \mathrm{~min}$. The digestion was stopped by adding ice cold PBS buffer $(5 \mathrm{~mL}$ PBS at $4^{\circ} \mathrm{C}$ ). The cells were then centrifuged at $425 \mathrm{~g}$ for 
Table 1. Study collective and results of DNA and morphological analysis

\begin{tabular}{|c|c|c|c|c|c|c|c|c|c|c|c|c|c|c|}
\hline \multicolumn{8}{|c|}{ Clinicopathological data } & \multicolumn{7}{|c|}{ DNA and morphological data } \\
\hline Case & Sex & Age & T-No. & Diagnosis & TNM & Stage & Grade & Ploidy & C size & C var & M size & M var & tri $M$ & tetra $\mathrm{M}$ \\
\hline \multirow[t]{4}{*}{1} & Male & 70 & $1^{*}$ & $\mathrm{ADC}$ & $\mathrm{pT} 1, \mathrm{pN} 0$ & I & $\mathrm{G} 2$ & $2,30 \mathrm{c}$ & 1 & 3 & 1 & 2 & No & No \\
\hline & & & $2 *$ & $\mathrm{AD}$ & & & High & $2,32 \mathrm{c}$ & 1 & 3 & 1 & 2 & No & No \\
\hline & & & 3 & $\mathrm{AD}$ & & & Low & $2,43 \mathrm{c}$ & 1 & 2 & 1 & 2 & No & No \\
\hline & & & 4 & AIS & pTis & & G2 & $3,20 \mathrm{c}$ & 2 & 4 & 2 & 3 & Yes & No \\
\hline \multirow[t]{4}{*}{2} & Female & 54 & 5 & $\mathrm{ADC}$ & $\mathrm{pT} 1, \mathrm{pN} 0$ & I & $\mathrm{G} 2$ & $2,42 \mathrm{c}$ & 1 & 2 & 2 & 2 & No & No \\
\hline & & & 6 & $\mathrm{AD}$ & & & Low & $2,49 \mathrm{c}$ & 1 & 2 & 2 & 2 & No & No \\
\hline & & & 7 & $\mathrm{AD}$ & & & Low & $2,40 \mathrm{c}$ & 1 & 2 & 1 & 2 & No & No \\
\hline & & & 8 & $\mathrm{AD}$ & & & Low & $2,17 \mathrm{c}$ & 1 & 2 & 1 & 2 & No & No \\
\hline \multirow[t]{3}{*}{3} & Male & 71 & 9 & $\mathrm{AD}$ & & & Low & $2,40 \mathrm{c}$ & 1 & 2 & 1 & 2 & No & No \\
\hline & & & 10 & AIS & pTis & & G 3-4 & $3,44 \mathrm{c}$ & 1 & 2 & 2 & 2 & No & No \\
\hline & & & 11 & $\mathrm{ADC}$ & pT1, pN0 & I & G3 & $2,43 \mathrm{c}$ & 2 & 2 & 1 & 2 & No & No \\
\hline \multirow[t]{5}{*}{4} & Male & 76 & 12 & $\mathrm{ADC}$ & pT3, pN0 & II & $\mathrm{G} 2$ & $3,61 \mathrm{c}$ & 2 & 4 & 3 & 3 & No & No \\
\hline & & & 13 & $\mathrm{ADC}$ & pT3, pN0 & II & $\mathrm{G} 2$ & $2,20 \mathrm{c}$ & 1 & 3 & 1 & 2 & No & No \\
\hline & & & 14 & $\mathrm{AD}$ & & & Low & $2,80 \mathrm{c}$ & 1 & 2 & 1 & 3 & No & No \\
\hline & & & 15 & $\mathrm{ADC}$ & $\mathrm{pT} 3, \mathrm{pN} 0$ & II & $\mathrm{G} 2$ & $2,51 \mathrm{c}$ & 1 & 2 & 1 & 2 & No & No \\
\hline & & & 16 & $\mathrm{AD}$ & & & Low & $2,20 \mathrm{c}$ & 1 & 3 & 2 & 3 & No & No \\
\hline \multirow[t]{2}{*}{5} & Male & 78 & 17 & $\mathrm{ADC}$ & $\mathrm{pT} 3, \mathrm{pN} 2$ & III & G3 & $2,90 \mathrm{c}$ & 1 & 3 & 2 & 3 & Yes & No \\
\hline & & & 18 & $\mathrm{AD}$ & & & Low & $2,20 \mathrm{c}$ & 1 & 2 & 2 & 3 & No & No \\
\hline \multirow[t]{5}{*}{6} & Male & 61 & $19^{*}$ & $\mathrm{ADC}$ & $\mathrm{pT} 1, \mathrm{pN} 0$ & I & $\mathrm{G} 2$ & $2,39 \mathrm{c}$ & 2 & 3 & 2 & 2 & No & No \\
\hline & & & $20^{*}$ & $\mathrm{AD}$ & & & High & $2,60 \mathrm{c}$ & 1 & 2 & 1 & 2 & No & No \\
\hline & & & 21 & $\mathrm{AD}$ & & & Low & $2,36 \mathrm{c}$ & 1 & 2 & 2 & 2 & No & No \\
\hline & & & $22 *$ & $\mathrm{ADC}$ & $\mathrm{pT} 1, \mathrm{pN} 0$ & I & $\mathrm{G} 2$ & $2,57 \mathrm{c}$ & 1 & 3 & 1 & 2 & No & No \\
\hline & & & $23^{*}$ & $\mathrm{AD}$ & & & High & $2,20 \mathrm{c}$ & 1 & 2 & 1 & 0 & No & No \\
\hline \multirow[t]{2}{*}{7} & Female & 55 & $24^{*}$ & $\mathrm{ADC}$ & pT3, pN2, M1 & III & G3 & $2,09 \mathrm{c}$ & 2 & 4 & 2 & 2 & No & Yes \\
\hline & & & $25^{*}$ & $\mathrm{AD}$ & & & High & $1,65 \mathrm{c}$ & 2 & 4 & 2 & 2 & No & No \\
\hline \multirow[t]{2}{*}{8} & Male & 50 & $26^{*}$ & $\mathrm{ADC}$ & pT3, pN2 & IV & G3 & $2,13 \mathrm{c}$ & 1 & 3 & 1 & 1 & No & Yes \\
\hline & & & $27^{*}$ & $\mathrm{AD}$ & & & High & $1,75 \mathrm{c}$ & 1 & 2 & 1 & 1 & No & No \\
\hline \multirow[t]{2}{*}{9} & Female & 52 & $28^{*}$ & $\mathrm{ADC}$ & pT1, pN1 & III & G3 & $3,05 \mathrm{c}$ & 2 & 4 & 2 & 2 & Yes & No \\
\hline & & & $29^{*}$ & $\mathrm{AD}$ & & & High & $1,75 \mathrm{c}$ & 1 & 2 & 1 & 1 & No & No \\
\hline 10 & Female & 70 & 30 & $\mathrm{ADC}$ & pT1, pN0 & I & $\mathrm{G} 2$ & $3,60 \mathrm{c}$ & 2 & 3 & 3 & 3 & No & No \\
\hline
\end{tabular}

*adenoma and adenocarcinoma sample adjacent to each other with morphological transition. Abbreviations: AD — adenoma; ADC — adenocarcinoma; AIS — adenocarcinoma in situ; T-No. — tumor sample number; C size — nuclear/core size; C var — core size variability; M size — mitosis size; $\mathrm{M}$ var — mitosis size variability; tri $\mathrm{M}$ - tripolar mitosis; tetra $\mathrm{M}$ — tetrapolar mitosis

$10 \mathrm{~min}$. About 6 to $8 \mathrm{~mL}$ of the supernatant was discarded and the cell nuclei were resuspended by mixing with a $1 \mathrm{~mL}$ pipette. The nuclei were then transferred onto adhesive glass slides (SuperFrost ${ }^{\circledR}$ Plus, Menzel-Gläser, Thermo Scientific) by applying $250 \mu \mathrm{L}$ of the solution to a cyto-centrifuge (400 rpm, $10 \mathrm{~min}$ ). Larger tissue debris was removed by prior filtration of the aliquot through a tissue Nylon biopsy bag (Shandon $^{\mathrm{TM}}$ Nylon Biopsy Bags, Thermo Scientific). The Feulgen staining was performed after air drying the slides at room temperature on the following day as described earlier [24]. The Feulgen stain represents a classical dying method for DNA that yields purple stained nuclei. The preparations were finally covered by Vitro-Clud ${ }^{\circledR}$ (R. Langenbrinck, Deutschland) and a cover slip (Menzel-Gläser, Thermo Scientific).

Static DNA cytometry was essentially performed as described earlier [24, 25]. Over 300 tumor cells nuclei as well as 30 reference non-tumor cells nuclei were manually selected. Lymphocytes and granulocytes were used as internal reference cells. The quality of the staining and measure- 

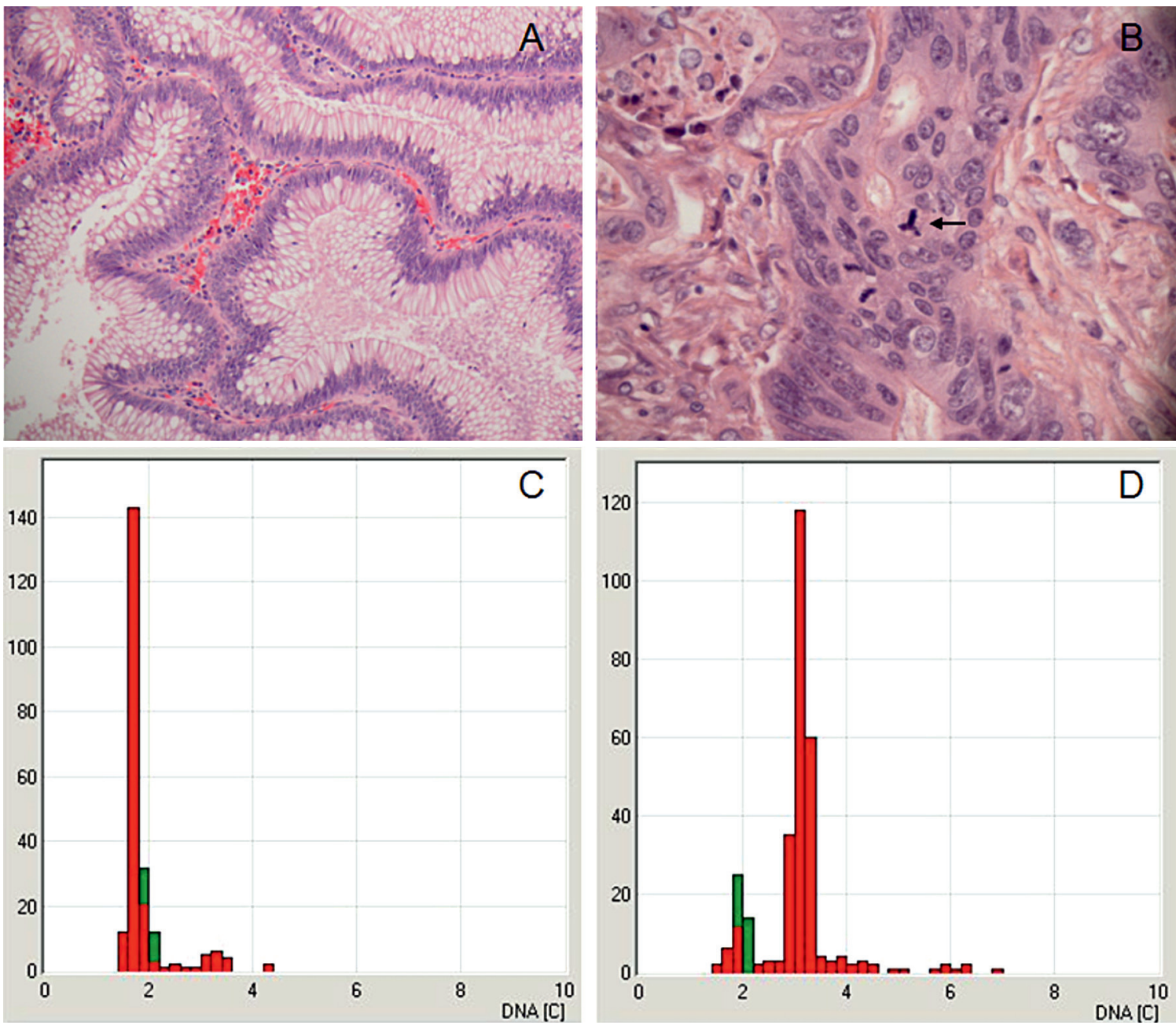

Figure 1. Morphology and DNA ploidy of a colon adenoma and adenocarcinoma. A, B. Morphology of an adenoma (case 6, sample 21; H \& E, magnification $\times 200$ ) and an adenocarcinoma (case 5, sample 17; H \& E, magnification $\times 630$ ), respectively. The tripolar mitosis of the carcinoma (B, see arrow) was associated with a near triploid DNA content of the tumor cells (2,9c, see Table 1); C, D. DNA ploidy analysis of an adenoma and its adjacent adenocarcinoma, respectively. The adenoma carried a hypodiploid DNA content (case 9, sample 29, Table 1) while the adenocarcinoma (case 9, sample 28, Table 1) showed a near triploid DNA ploidy state which suggests that the transition to malignancy was accompanied by a duplication of the hypodiploid chromosomal complement

ments were validated by the manufacturer of the cytometry system, Dr. Olaf Ahrens. By comparing the reference cells with the cells of interest, a histogram was created (Figure 1). Based on the histogram and the evaluated parameters the DNA content and the ploidy status of the tumor cells were assessed (Table 1).

The samples were measured with an ICM cytometry system (Dr. Olaf Ahrens, Bargteheide, Germany). This is a unit consisting of a Nikon microscope linked to a CCD-camera and a computer software that is able to assess the DNA content of cell nuclei. It relies on the measurement of the optical density of the Feulgen-stained nuclei [26]. Different parameters, such as the colour concentration of the cell nuclei, size of the nucleus and the ploidy of each tumor cell could be determined by the DNA cytometry system (Table 1).

\section{Results}

\section{Clinicopathological analysis}

Overall, we analysed 30 samples divided into 15 adenomas and 15 carcinomas from 10 patients (Table 1 ). On the one hand special attention was taken to analyse carcinomas which morphologically had developed from adenomas, i.e. samples in which the adenoma-carcinoma-sequence was evident (cases 1, $6,7,8,9)$. On the other hand, we analysed samples 
of adenomas and carcinomas from the same patient in which there were no morphological signs of a step -wise transition between the benign and malignant tumor stage (cases 1, 2, 3, 4, 5, 6). Furthermore, in some of these cases several distinct carcinoma and adenoma samples were evaluated either because of multiple tumor formations (cases 3, 4, 6) or because morphological distinct tumor areas were detectable (case 4). In one case, a single carcinoma sample was investigated (case 10). With respect to the histotype, all carcinomas had typical intestinal type morphology except for one case with a signet ring cell carcinoma (case 4, tumor samples 13 and 15). Two carcinomas were in an early stage (in situ) while all other cancers represented invasive carcinomas (Table 1).

\section{The core classification of adenomas and adenocarcinomas}

The core classification provided semi-quantitative parameters for the morphological analysis of the tumor samples (Table 1). There was no obvious correlation between the morphology parameters (core size, mitosis size and their size variability) and tumor stage, e.g. sample 30 of a stage I tumor had increased size and variability parameters. However, there was a correlation between the presence of either tripolar or tetrapolar mitoses with advanced tumor stage. Four out of 5 tumors (samples 17, 24, 26, 28) were associated with stage III or IV disease while only one carcinoma in situ harboured a tripolar mitosis. Furthermore, tripolar mitoses were an indicator of a near triploid DNA content (samples 4, 17, 28). In addition, all carcinomas with increased DNA values (samples 4, 10, 12, 17, 28, 30) had also increased morphology size values, which was particularly evident for the mitosis size.

\section{DNA ploidy status of adenomas and adenocarcinomas}

The DNA content of the carcinomas ranged from $2,09 \mathrm{c}$ to $3,61 \mathrm{c}$ with a mean DNA index of $2,59 \mathrm{c}$. Thus, there was a considerable variation in the DNA content. Stage I carcinomas were mostly hyperdiploid ranging from $2,3 \mathrm{c}$ to $2,57 \mathrm{c}$ (samples $1,5,11,19,22$ ) except for one tumor with a near tetraploid DNA content of 3,6c (sample 30). In stage II or higher cases (samples 12, 13, 15, 17, 24, 26, 28), there were more tumors with an increased DNA content. In particular, the only two carcinomas with lymph node metastases showed a near triploid DNA content of 2,9c and 3,05c respectively (samples 17 and 28). However, there was no clear relationship between the tumor stage and increased ploidy which is most obvious from the two carcinoma in situ cases (samples 4 and 10) which carried near triploid DNA contents of $3,2 \mathrm{c}$ and $3,44 \mathrm{c}$, respectively.

The DNA content in adenomas ranged from $1,65 \mathrm{c}$ to $2,80 \mathrm{c}$ with a mean DNA index of $2,3 \mathrm{c}$. Interestingly, there were 3 adenomas adjacent to carcinomas with a hypodiploid DNA content (samples 25, 27, 29). Actually these initial cases prompted the initiation of the study. However, it was not a universal finding as two other adenomas with a transition to a carcinoma harboured hyperdiploid DNA values of 2,2c and 2,6c (samples 20 and 23). Most adenomas without signs of malignant transformation (samples 3, 6, 7, 8, 9, 18, 21) had hyperdiploid DNA values ranging from $2,17 \mathrm{c}$ to $2,49 \mathrm{c}$ ). The only exception was the adenoma of case 4, a patient with a distinct stage II cancer, which harboured tumor cells of near triploid DNA content of 2,80c (sample 14).

\section{Discussion}

Chromosomal instability is a well-accepted characteristic of colon cancer [27]. Similarly, DNA ploidy measurement has been established as a prognostic factor [28]. In addition, specific chromosomal imbalances have been associated with tumor behaviour [5, 29-31]. However, the detection of chromosomal imbalances by FISH or DNA ploidy measurement has not yet entered clinical practice which may be due to the fact that these changes seems to occur at an early phase of tumorigenesis [32].

We recently analysed the potential prognostic impact of the ploidy status of different cancer types by transforming the information on chromosomal changes of tumor karyotypes of the Mitelman database into ploidy information [33]. The data suggested that a near triploid chromosomal content might be a criterion of more aggressive cancer types including colon carcinomas. In addition, we established a morphology based classification, the core classification, which correlated with the ploidy level of cancer specimens [24, 25, 34]. The purpose of the present study was to evaluate these findings in colon carcinogenesis with specific attention to the adenoma-carcinoma sequence.

The main results of the study may be summarized as follows. 1) DNA ploidy changes are already consistently detectable in colon adenomas. They are usually associated with hyperdiploidy. 2) Adenoma tissue adjacent to carcinomas, however, may carry a hypodiploid DNA content while the nearby carcinoma samples were hyperdiploid. Hypodiploidy may thus represent a transition state to near triploid carcino- 
mas. 3) The size of tumor nuclei and mitoses usually reflects the ploidy level of colon tumors. Specifically, triploid mitoses may point to a near triploid DNA content. 4) Triploidy per se cannot be equated with tumor aggressiveness as it may already be found in adenoma or adenocarcinoma in situ. 5) Tripolar and tetrapolar mitoses in invasive colon cancer, however, are potential indicators of an advanced chromosomal instability and seemed to be associated with advanced tumor stages.

Steinbeck et al. and Ried et al. already reported chromosomal changes in colorectal adenomas $[32,35]$. These studies indicated in particular the presence of DNA and chromosomal gains in early tumorigenesis. Our study suggested that hypodiploidy and thus chromosomal loss may occur in colon adenomas. This may be particularly relevant in those adenomas that have the propensity to progress to invasive carcinoma. We feel that this is a significant observation although it is difficult to judge the frequency and importance of it due to our limited number of cases. The loss of genetic material being potentially associated with the inactivation of tumor suppressor genes may play a similarly important role in tumor progression than the activation of oncogenes [27].

The study supports our previous notion that near-triploidy might serve as indicator for invasive carcinomas with a more aggressive phenotype [24, 33]. However, it must be stressed that the triploidy per se does not imply a simple yes or no distinction of the tumor behaviour as it may occur in benign tumors as well as adenocarcinoma in situ. In addition, it can be associated with hydatidiform mole, a pseudotumor formation of the uterus simulating pregnancy [36]. Thus, the interpretation of triploidy is strongly tissue and context dependent. There may be a subset of (non -invasive) triploid lesions/tumors that behave in an indolent fashion. In invasive carcinoma, however, this genomic state seems to represent a form of chromosomal instability which favours tumor aggressiveness, thus representing an enabling hallmark of cancer [37].

Hypodiploidy may constitute a transition state to triploidy since the doubling of the chromosome content of a hypodiploid cell may yield a near triploid state. Similarly, the chromosomal splitting of a triploid tumor cell does result in hypodiploidy which has been related to an unfavourable prognosis in acute lymphoblastic leukaemia and multiple myeloma [38, 39, 40]. In carcinomas, there is also evidence for a prognostic influence of hypodiploidy. Specifically it has been shown that endometrioid carcinoma of the uterus bearing a good overall survival are generally hyperdiploid whereas the same tumor subtype in the ovary carrying a worse prognosis is usually hypodiplo- id [41]. In addition, small cell lung cancer, the most aggressive pulmonary cancer subtype, is generally a hypodiploid tumor [24].

To our knowledge, the association of tripolar mitoses with a triploid DNA content was first described in normal rat cells [42]. It is frequently associated with octaploid cells that undergo divisions in which 2 triploid cells and 1 diploid cell are generated $(8 n \rightarrow$ $3 n+3 n+2 n)$. In normal cell, this does happen only very rarely. In contrast, it is a frequent event in cancer cells. The above equation is actually represented by the DNA histogram of carcinoma cells that usually show a minor diploid peak together with the major triploid one (Figure 1D). A similar observation was also made in lung cancer [24, 34].

While polyploidy in the liver has already been described long time ago it has recently been shown that aneuploidy also occurs in normal human hepatocytes [43-45]. Polyploidy frequently represents a precursor state of aneuploidy [46, 47]. However, it is not a prerequisite for the development of aneuploidy [48]. Similarly, it is important to note that multipolar spindle formation and chromosome segregation defects are potential feature of non-neoplastic cells that do not necessarily result in cell death [44]. This is particularly true for cancer cells which have evolved sophisticated mechanisms to cope with frequently observed triploidy and tripolar mitoses [24, 33, 49].

In summary, the core classification of cancer being here applied for the first time to colon epithelial tumors provides information on the ploidy status of colon cancer and thus its chromosomal content. The study represents to our knowledge the first attempt to characterize the ploidy status of the adenoma-carcinoma-sequence of colon cancer by analysing distinct areas from the same tumor of single patients by DNA cytometry. We present data that hypodiploidy may represent a transition state from adenoma to carcinoma in a subset of tumors and that near-triploidy may be associated with a more aggressive course of the disease. However, the interpretation of tripolar mitoses and triploidy is largely dependent on the cell type (normal $v s$. cancer) and tissue context (invasive $v s$. non-invasive cancer). Furthermore, its interpretation may be distinct for different cancer histotypes. Aneuploidy and multipolar mitoses are frequent and relevant findings in cancer cells. Their features and impact for tumor biology deserves further studies.

\section{Acknowledgement}

The technical and intellectual assistance of Dr. Olaf Ahrens in the DNA analysis of the colorectal tumor samples is gratefully acknowledged. 


\section{References}

1. Parkin DM, Bray F, Ferlay J, Pisani P. Global cancer statistic 2002. CA Cancer J Clin. 2005;55:74-108. PMID: 15761078.

2. Jemal A, Siegel R, Xu J, Ward E. Cancer statistic 2010. CA Cancer J Clin. 2010;60:277-300. doi: 10.3322/caac.20073.

3. Krebs in Deutschland 2009/2010. 9. Auflage. Robert Koch -Institut (Hrsg.) und die Gesellschaft der epidemiologischen Krebsregister in Deutschland e.V. (Hrsg). Berlin 2013. http:// //www.gekid.de/Doc/krebs_in_Deutschland_2009_2010.pdf.

4. Laohavinij S, Maneechavakajorn J, Techatanol P. Prognosis factors for the survival in colorectal cancer patients. $\mathrm{J}$ Med Assoc Thai. 2010;93:1156-1166. PMID: 15516006.

5. Bosman FT, Carneiro F, Hruban RH, Theise ND. WHO Classification of tumours of the digestive system. $4^{\text {th }}$ edition. Lyon; 2010.

6. Morson B. The Polyp-Cancer-Sequence in the Large Bowel. Section of Proctology, 1974, Volume 67 (St. Mark's Hospital, City Road, London ECL, UK). PMID: 4853754.

7. Neri E, Faggioni L, Cini L, Bartolozzi C. Colonic polyps: inheritance, susceptibility, risk evaluation and diagnostic management. Cancer Manag Res. 2010;3:17-24. doi: 10.2147/ /CMR.S15705.

8. Morson BC, Jass JR. Precancerous lesions of the gastrointestinal tract. A histological classification. London: Bailliere-Tindall; 1985.

9. Goh HS, Jass JR. DNA content and the adenoma-carcinoma sequence in the colorectum. J Clin Pathol. 1986;39:387-392. doi: $10.1136 / j$ cp.39.4.387.

10. Konishi F, Morson BC. Pathology of colorectal adenomas: a colonoscopic survey. J Clin Pathol. 1982;35:830-841. doi: 10.1136/jcp.35.8.830.

11. Quirke P, Fozard JB, Dixon MF, Dyson JE, Giles GR, Bird CC. DNA aneuploidy in colorectal adenomas. Br J Cancer. 1986;53:477-481. PMID: 3707842.

12. Sedivy R, Wolf B, Kalipciyan M, Steger GG, Kerner-Hanunsch J, Mader RM. Genetic analysis of multiple synchronous lesions of the colon adenoma-carcinoma sequence. $\mathrm{Br}$ J Cancer. 2000;82:1278-1282. doi: 10.1054/bjoc.1999.1091.

13. Weinberg RA. The Biology of Cancer. Baltimore: Garland Science; 2006.

14. Sieber OM, Heinimann K, Tomlinson IP. Genomic instability — the engine of tumorigenesis? Nat Rev Cancer. 2003;3:701-708. doi: $10.1038 / \mathrm{nrc} 1170$.

15. Fearon E, Vogelstein B. A Genetic model for colorectal tumorigenesis. Cell. 1990;61:759-767. doi: 10.1016/0092-8674(90)90186-I.

16. Vogelstein B, Papadopoulos N, Velculescu VE, Zhou S, Diaz LA, Kinzler KW. Cancer genome landscapes. Science. 2013;339:1546-1558. doi: 10.1126/science.1235122.

17. Walther B, Walther I, Chen Y, Petersen I. GNAS1 mutations in gastrointestinal tumors. Folia Histochem Cytobiol. 2014;52:90-95. doi: 10.5603/FHC.2014.0011.

18. Smith G, Carey FA, Beattie J et al. Mutation in APC, Kirsten-ras and P53 - alternative genetic pathway to colorectal cancer. Proc Natl Acad Sci. 2002;99:9433-9438. doi: 10.1073/ /pnas.122612899.

19. Beckman RA, Loeb LA. Genetic instability in cancer: theory and experiment. Semin Cancer Biol. 2005;15:423-435. doi: 10.1016/j.semcancer.2005.06.007.

20. Vielh P, Magdelenat H, Remvikos Y, Dutrillaux B. Analysis of DNA content. In: Flow cytometry. $1^{\text {st }}$ ed. New York: Igaku-Shoin; 1991;21-27.

21. Weaver BA, Cleveland DW. Does aneuploidy cause cancer? Curr Opin Cell Biol. 2006;18:658-667. doi: 10.1016/j.ceb. 2006.10.002
22. Baretta A, Marzullo F, Pellecchia A et al. DNA flow cytometry, p53 levels and proliferative cell nuclear antigen in human colon dysplastic, precancerous and cancerous tissues. Anticancer Res. 1998;18:1677-1682. PMID: 9673389.

23. Löfberg R, Caspersson T, Tribukait B, Ost A. Comparative DNA analyses in longstanding ulcerative colitis with aneuploidy. Gut. 1989;30:1731-1736. doi: 10.1136/gut.30.12.1731.

24. Petersen I, Kotb WF, Friedrich KH, Schlüns K, Böcking A, Dietel M. Core classification of lung cancer: Correlating nuclear size and the mitosis with ploidy and clinicopathological parameters. Lung Cancer. 2009;5:312-318. doi: 10.1016/j. lungcan.2008.12.013.

25. Kotb WF, Blind C, Friedrich $\mathrm{KH}$ et al. Core classification of head and neck squamous cell carcinomas: correlations between morphology, DNA ploidy and HPV infection. Pathol Res Pract. 2010;206:768-771. doi: 10.1016/j.prp.2010.07.011.

26. Praça-Fontes MM, Carvalho CR, Clarindo WR. C-value reassessment of plant standards: an image cytometry approach. Plant Cell Rep. 2011;30:2303-2312. doi: 10.1007/ /s00299-011-1135-6.

27. Habermann JK, Brucker CA, Freitag-Wolf S et al. Genomic instability and oncogene amplifications in colorectal adenomas predict recurrence and synchronous carcinoma. Mod Pathol. 2011;24:542-555. doi: 10.1038/Modpathol.2010.217.

28. Araujo SE, Bernardo WM, Habr-Gama A, Kiss DR, Cecconello I. DNA ploidy status and prognosis in colorectal cancer: a meta-analysis of published data. Dis Colon Rectum. 2007;50:1800-1810. PMID: 17874166.

29. Knösel T, Petersen S, Schwabe $\mathrm{H}$ et al. Incidence of chromosomal imbalances in advanced colorectal carcinomas and their metastases. Virchows Arch. 2002;440:187-194. PMID: 11964050.

30. Knösel T, Schlüns K, Stein U et al. Chromosomal alterations during lymphatic and liver metastasis formation of colorectal cancer. Neoplasia. 2014;6:23-38. PMID: 15068668.

31. Brosens RP, Belt EJ, Haan JC et al. Deletion of chromosome 4q predicts outcome in stage II colon cancer patients. Anal Cell Pathol. 2010;33:95-104. doi: 10.3233/ACP-CLO-2010-0531.

32. Ried T, Knutzen R, Steinbeck R et al. Comparative Genomic Hybridization reveals a specific pattern of chromosomal gains and losses during the genesis of colorectal tumors. Genes, Chromosomes Cancer. 1996;15:234-245. PMID: 8703849.

33. Schulze S, Petersen I. Gender and ploidy in cancer survival. Cell Oncol (Dordr). 2011;34:199-208. doi: 10.1007/s13402-011-0013-0.

34. Amin Kotb WFM, Petersen I. Morphology, DNA ploidy and HPV in lung cancer and head and neck cancer. Pathol Res Pract. 2012;208:1-8. doi: 10.1016/j.prp.2011.10.009.

35. Steinbeck RG, Heselmeyer KM, Auer GU. DNA ploidy in human colorectal adenomas. Anal Quant Cytol Histol. 1994;16:196-202. PMID: 7916847.

36. Joergensen MW, Niemann I, Rasmussen AA et al. Triploid pregnancies: genetic and clinical features of 158 cases. $\mathrm{Am}$ J Obstet Gyncecol. 2014;211:370.e1-e19. doi: 10.1016/j.ajog. 2014.03.039.

37. Hanahan D, Weinberg RA. Hallmarks of cancer: The next generation. Cell. 2011;144:646-674. doi: 10.1016/j.cell. 2011.02.013.

38. Rajkumar SV. Multiple myeloma: 2011 update on diagnosis, risk-stratification, and management. Am J Hematol. 2011;86:57-65. doi: 10.1002/ajh.21913.

39. Harrison CJ, Moorman AV, Broadfield ZJ et al. Three distinct subgroups of hypodiploidy in acute lymphoblastic leukaemia. Br J Haematol. 2004;125:552-559. doi: 10.1111/j. 1365-2141.2004.04948.x. 
40. Moorman AV, Harrison CJ, Buck GA et al. Karyotype is an independent prognostic factor in adult acute lymphoblastic leukemia (ALL): analysis if cytogenetic data from patients treated on the Medical Research Council (MRC) UKALLXII/ /Eastern Cooperative Oncology Group (ECOG) 2993 trial. Blood. 2007;109:3189-3197. doi: 10.1182/blood-2006-10-051912.

41. Atkin NB. Frequency of hyperdiploid chromosome complements in endometrioid tumor of the endometrium whereas similar tumors in the ovary tend to show hypodiploidy: a significant difference that may not be distinguishable by flow cytometry of DNA content. Cytogenet Genome Res. 2002;97:39-42. doi: 10.1159/000064053.

42. Pera F, Rainer B. Studies of multipolar mitoses in euploid tissue cultures. I. Somatic reduction to exactly haploid and triploid chromosome sets. Chromosoma. 1973;42:71-86. PMID: 4123256.

43. Duncan AW, Taylor MH, Hickey RD et al. The ploidy conveyor of mature hepatocytes as a source of genetic variation. Nature. 2010;467:707-710. doi: 10.1038/nature09414.
44. Duncan AW, Hanlon Newell AE et al. Frequent aneuploidy among normal human hepatocytes. Gastroenterology. 2012;142:25-28. doi: 10.1053/j.gastro.2011.10.029.

45. Duncan AW. Aneuploidy, polyploidy and ploidy reversal in the liver. Semin Cell Dev Biol. 2013;24:347-356. doi: 10.1016/j. semcdb.2013.01.003.

46. Bazeley PS, Nestor Kalinoski AL et al. A model for random genetic damage directing selection of diploid or aneuploid tumours. Cell Prolif. 2011;44:212-223. doi: 10.1111/j. 1365-2184.2011.00746.x.

47. Ganem NJ, Storchova Z, Pellman D. Tetraploidy, aneuploidy and cancer. Curr Opin Genet Dev. 2007;17:157-162. doi: 10.1016/j.gde.2007.02.011.

48. Holland AJ, Cleveland DW. Losing balance: the origin and impact of aneuploidy in cancer. EMBO Rep. 2012;13:501-514. doi: 10.1038/embor.2012.55.

49. Krämer A, Maier B, Bartek J. Centrosome clustering and chromosomal (in)stability: a matter of life and death. Mol Oncol. 2011;5:324-335. doi: 10.1016/j.molonc.2011.05.003.

Submitted: 10 August, 2014

Accepted after reviews: 5 February, 2015 Available as AoP: 13 February, 2015 